\title{
Revisiting Fisher Equation in BRICS Countries
}

\section{Bahmani-Oskooee $\mathrm{M}^{1 *}$, Jing-Ping $\mathrm{Li}^{2}$ and Chang $\mathrm{T}^{3}$}

${ }^{1}$ Department of Economics, The Center for Research on International Economics, University of Wisconsin-Milwaukee, USA

${ }^{2}$ Department of Finance and Banking, Shanxi University of Finance and Economics, China

${ }^{3}$ Department of Finance, Feng Chia University, Taiwan

\begin{abstract}
In this paper we test the Fisher effect by using monthly data from each of the four BRICS countries (i.e., Brazil, Russia, India, China, and South Africa). The results by applying threshold cointegration method reveal that the Fisher effect is valid in all countries except South Africa, implying that nominal interest rates adjust to inflation in the long run.
\end{abstract}

Keywords: Threshold cointegration; Fisher equation; BRICS

\section{Introduction}

According to the quantity theory of money, $\mathrm{x} \%$ increase in the money supply results in $\mathrm{x} \%$ inflation, in the long run. If nominal interest rate adjusts to inflation in the long run, then the Fisher effect is said to be in place. This means that both nominal interest rate and inflation rate should be cointegrated in the long run ${ }^{1}$. Therefore, the Fisher effect basically implies that in the long run nominal interest rate adjusts to inflation rate or expected rate of inflation. Alternatively, the nominal interest rate and inflation rate should have a cointegrating relationship in the long run or the real interest rate which combined the nominal interest rate and inflation rate must be mean reverting or stationary.

Most studies which have tried to test the Fisher effect have either tested for cointegration between nominal interest rate and inflation or have applied different unit-root tests to establish stationarity of the real interest rates. An implicit assumption inherent in standard unitroot tests or standard cointegration methods is the linear adjustment of variables which imply asymmetry effects. However, recent studies in asymmetry analysis which utilize nonlinear models supports the notion that macro variables do have asymmetric effects on each other. For example on the asymmetric effects of U.S. stock market on consumption see Apergis et al. [1]; on the asymmetric effects of exchange rate changes on domestic prices see Delatte [2]; on interest rate pass-through mechanism to deposit rates see Verheyen [3]; on asymmetry S-curve see Bahmani-Oskooee et al. [4]; On asymmetry effects of exchange rate changes on the trade balance see BahmaniOskooee et al. [5,6]; On the asymmetric effects of exchange rate changes on the demand for money see Bahmani-Oskooee et al. [7]; On the asymmetric effects of output gap on inflation see Valadkhani [8] and on the asymmetric effects of income and interest rate on housing prices in the U.S. see Bahmani-Oskooee et al. [9].

The evidence from many of the studies mentioned above indicates that the assumption of symmetric adjustments yield poor results as compared to models that deal with asymmetric effects. Since testing for asymmetric effects introduce nonlinear adjustment of variables, the new nonlinear models provide relatively more support for our theoretical expectation. As such we are motivated to apply the Autoregressive Distributed Lag (hereafter, ADL) test for threshold (asymmetric) cointegration in our study. Such test that is introduced by Li et al. [10] is applied to test the Fisher effect in BRICS countries. To that end, data are discussed in Section 4. The model and method are

${ }^{1}$ Note that due to adjustment lags, nominal interest rates do not adjust to inflation instantaneously in the short run. introduced in Section 5. Finally, while Section 6 presents our empirical results, Section 7 provides a summary.

\section{Data}

Monthly data over the period January 1996- September 2015 from each of the five BRICS countries (i.e., Brazil, Russia, India, China, and South Africa) are employed to carry out the empirical analysis. All consumer price indices, CPI $(2005=100)$ and nominal interest rates are taken from the Data stream. Tables 1 and 2 report summary

\begin{tabular}{|c|c|c|c|c|c|}
\hline & Brazil & Russia & India & China & South Africa \\
\hline Mean & 16.71 & 23.15 & 7.51 & 3.83 & 9.95 \\
\hline Median & 15.80 & 13.00 & 6.50 & 2.70 & 9.00 \\
\hline Maximum & 45.90 & 160.00 & 12.00 & 12.72 & 21.85 \\
\hline Minimum & 7.11 & 5.25 & 6.00 & 0.99 & 5.00 \\
\hline Std. Dev. & 7.43 & 25.68 & 1.82 & 2.84 & 4.21 \\
\hline Skewness & 1.35 & 2.73 & 1.01 & 1.93 & 0.71 \\
\hline Kurtosis & 5.08 & 11.51 & 3.07 & 5.67 & 2.62 \\
\hline Jarque-Bera & 114.93 & 1009.3 & 40.31 & 216.98 & 21.38 \\
\hline Probability & 0.000 & 0.000 & 0.000 & 0.000 & 0.000 \\
\hline Observations & 237 & 237 & 237 & 237 & 237 \\
\hline
\end{tabular}

Table 1: Summary statistics of nominal interest rate.

\begin{tabular}{|c|c|c|c|c|c|}
\hline & Brazil & Russia & India & China & South Africa \\
\hline Mean & 0.005 & 0.012 & 0.005 & 0.002 & 0.004 \\
\hline Median & 0.004 & 0.008 & 0.006 & 0.001 & 0.0039 \\
\hline Maximum & 0.028 & 0.324 & 0.047 & 0.025 & 0.0241 \\
\hline Minimum & -0.006 & -0.004 & -0.0212 & -0.015 & -0.011 \\
\hline Std. Dev. & 0.003 & 0.023 & 0.008 & 0.007 & 0.0046 \\
\hline Skewness & 1.702 & 10.449 & 0.227 & 0.292 & 0.477 \\
\hline Kurtosis & 9.666 & 134.81 & 5.669 & 3.198 & 4.371 \\
\hline Jarque-Bera & 550.98 & 175139 & 73.113 & 3.736 & 27.422 \\
\hline Probability & 0.000 & 0.000 & 0.000 & 0.154 & 0.0000 \\
\hline Observations & 237 & 237 & 237 & 237 & 237 \\
\hline
\end{tabular}

Table 2: Summary statistics of inflation rate.

*Corresponding author: Bahmani-Oskooee M, Department of Economics, The Center for Research on International Economics, University of WisconsinMilwaukee, USA, Tel: 4142294334; E-mail: bahmani@uwm.edu

Received June 14, 2016; Accepted August 26, 2016; Published August 30, 2016

Citation: Bahmani-Oskooee M, Li JP, Chang T (2016) Revisiting Fisher Equation in BRICS Countries. J Glob Econ 4: 210. doi: 10.4172/2375-4389.1000210

Copyright: (c) 2016 Bahmani-Oskooee M, et al. This is an open-access article distributed under the terms of the Creative Commons Attribution License, which permits unrestricted use, distribution, and reproduction in any medium, provided the original author and source are credited. 
statistics of both nominal interest rate and inflation rate, respectively, for each country in the sample. We find that Russia and China have the highest and lowest mean inflation rates of $12 \%$ and $0.2 \%$, respectively. Russia and China also have the highest and lowest nominal interest rate of 23.15 and 3.83 , respectively.

\section{The ADL Test for Threshold Cointegration}

As mentioned before, the adopted methodology in this paper is based on the threshold cointegration analysis that is introduced by $\mathrm{Li}$ et al. [10]. We begin first with the following specification:

$$
n i_{t}=\alpha_{0}+\alpha_{1} \pi_{t}+u_{t}
$$

Where, $n i_{t}$ is the logarithm of the nominal interest rate; $\pi_{t}$ represents the inflation rate, and $u_{t}$ is the error term. The threshold ADL regression model of Fisher equation takes the following form:

$$
\begin{gathered}
\Delta n i_{t}=\beta_{0}+\beta_{1} n i_{t-1} I_{t}+\beta_{2} n i_{t-1}\left(1-I_{t}\right)+\beta_{3} \pi_{t-1} I_{t}+\beta_{4} \pi_{t-1}\left(1-I_{t}\right)+ \\
\beta_{5} \Delta n i_{t-1}+\beta_{6} \Delta n i_{t-2}+\beta_{7} \Delta \pi_{t}+\beta_{8} \Delta \pi_{t-1}+\beta_{9} \Delta \pi_{t-2}+\varepsilon_{t}
\end{gathered}
$$

Where, $I_{t}$ denotes two indicators, $I_{t}^{a}=I\left(E_{t-1}<E_{t-1}^{*}(\tau)\right)$ and $I_{t}^{b}=I\left(\Delta E_{t-1}<\Delta E_{t-1}^{*}(\tau)\right)$.

In (2) if we adopt the first indicator, then we replace $I_{t}$ with $I_{t}^{a}$ and if the second indicator is adopted, then we replace $I_{t}$ with $I_{t}^{b}$. In either indicator, $E_{t}$ is the estimated error correction term. Note that the adjustment speed which is measured by $\beta_{\mathrm{i}}(i=1,2,3,4)$ do vary in this set up which is what makes the threshold ADL model to be different than a standard ADL specification. Here, only two lags of $\Delta n i_{t}$ and $\Delta \pi_{t}$ are included in the regression so that we do not lose too many degrees of freedom. The lag-selection is guided by the partial autocorrelation function (PACF) of $\Delta n i_{t}$
Two tests are proposed for threshold cointegration by Li and Lee [10]. One is due to Boswijk [11] denoted by BO test under which we test the coefficients of both $n i_{t-1}$ and $\pi_{t-1}$ in the testing regression. The second test known as BDM test is by Banerjee et al. [12]. Under this test we add lead of $\pi_{t-1}$ to the regression so that the asymptotic results are valid in the absence of strict exogeneity. The null hypotheses under both tests are outlined as:

$$
\text { BO test, } H_{0}: \beta_{1}=\beta_{2}=\beta_{3}=\beta_{4}=0
$$$$
\text { BDM test, } \mathrm{H}_{0}: \beta_{1}=\beta_{2}=0
$$

In the absence of any rule for adopting Indicator A versus B in our model, the recommendation is to select the adjustment mechanism that is based on a set criterion such as the Akaike Information criteria (AIC) or Schwartz criteria (SC) [13].

\section{Empirical Results and Policy Implications}

By using the AIC model selection criterion, the ADL model with the Indicator A is favored in all the cases except in Brazil and South Africa. This means that for Russia, India, and China, we use ADL model with Indicator A function and Russia and South Africa, we use ADL model with Indicator B function. Tables 3 and 4 report the results from our ADL test for threshold cointegration using the Indicator A and Indicator B functions, respectively. The results in Tables 3 and 4 indicate that the null hypothesis is rejected in favor of the alternative hypothesis in only four cases, Brazil, Russia, India, and China. These findings provide strong evidence in favor of relationship between

\begin{tabular}{|c|c|}
\hline Brazil & $E_{t}^{*}(\tau)=5.079, \tau=0.826$, BO stat $: 26.169, B M D$ stat $: 22.463, A I C=1697.926$ \\
\hline Russia & 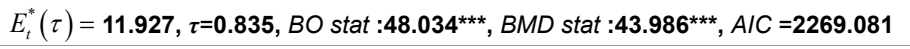 \\
\hline India & 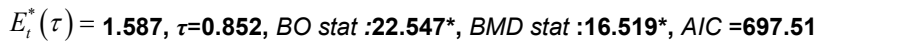 \\
\hline China & $E_{t}^{*}(\tau)=\mathbf{0 . 9 0 1}, \boldsymbol{\tau}=\mathbf{0 . 8 1 4}$, BO stat $: 17.388, B M D$ stat $: 16.827^{*}, A I C=1008.491$ \\
\hline S. Africa & $E_{t}^{*}(\tau)=1.38, \tau=0.648$, BO stat $: 12.599, B M D$ stat $: 11.742, A I C=888.655$ \\
\hline
\end{tabular}
nominal interest rate and inflation rate in BRICS countries, except South Africa.

Our findings imply that if monetary policy results in $5 \%$ inflation

\section{Note}

The critical values for BO statistic and BDM statistic are tabulated at Li and Lee's Table 1 of their paper.

The critical values of BO test for $10 \%, 5 \%$, and $1 \%$ are $22.11,24.67$, and 30.09 , respectively.

The critical values of BDM test for $10 \%, 5 \%$, and $1 \%$ are $16.24,18.66$, and 23.72 , respectively.

\begin{tabular}{|c|c|}
\hline Brazil & $E_{t}^{*}(\tau)=-1.191, \tau=0.153$, BO stat $: 33.684^{\star * *}, B M D$ stat $: 31.905^{\star * *}, A / C=1691.003$ \\
\hline Russia & $E_{t}^{*}(\tau)=0.028, \tau=0.555$, BO stat $: 44.095^{\star * *}, B M D$ stat $: 44.023^{* * *}, A I C=2272.491$ \\
\hline India & $E_{t}^{*}(\tau)=-0.194, \tau=0.148$, BO stat $: 17.524, B M D$ stat $: 11.699, A I C=702.326$ \\
\hline China & $E_{t}^{*}(\tau)=-0.029, \tau=0.496, B O$ stat $: 15.032, B M D$ stat $: 14.384, A I C=1010.786$ \\
\hline S. Africa & 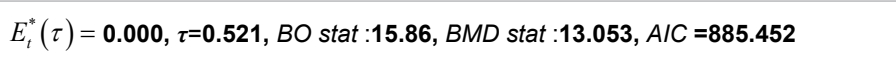 \\
\hline
\end{tabular}

***, **, and * indicates significance at the $0.01,0.05$ and 0.1 levels, respectively.

The number in parenthesis indicates the robust t-statistic.

Table 3: Conditional threshold ADL model of fisher equation with indicator $A$.

Note

The critical values for BO statistic and BDM statistic are tabulated at Li and Lee's Table 1 of their paper. The critical values of BO test for $10 \%, 5 \%$, and $1 \%$ are 20.90

23.43 , and 28.66, respectively.

The critical values of BDM test for $10 \%, 5 \%$, and $1 \%$ are $14.53,16.84$, and 21.46 , respectively.

***, **, and * indicates significance at the $0.01,0.05$ and 0.1 levels, respectively.

The number in parenthesis indicates the robust t-statistic.

Table 4: Conditional threshold ADL model of fisher equation with indicator B. 
Citation: Bahmani-Oskooee M, Li JP, Chang T (2016) Revisiting Fisher Equation in BRICS Countries. J Glob Econ 4: 210. doi: 10.4172/23754389.1000210

in BRICS, the nominal interest rate in the economy of those 4 countries (Brazil, Russia, India, and China) would eventually also increase by $5 \%$. Therefore, a change in the money supply shouldn't have an effect on the real interest rate. If the real interest rate isn't affected, then all changes in inflation must be reflected in the nominal interest rate, which is exactly what the Fisher effect claims.

\section{Summary and Conclusion}

The Fisher effect asserts that monetary policy that may result in $\mathrm{x} \%$ inflation, eventually will push the nominal interest rate up by $\mathrm{x} \%$, leaving the real interest rate unchanged. We employ the ADL test for threshold cointegration recently introduced by $\mathrm{Li}$ et al. [10] to verify the Fisher effect in BRICS countries. The Monte Carlo simulations of Li et al. [10] shows that their test do not suffer from low power and have good size properties. Our empirical results support Fisher effect in BRICS countries, except in South Africa.

\section{References}

1. Apergis N, Miller S (2006) Consumption Asymmetry and the Stock Market: Empirical Evidence. Economics Letters 93: 337-342.

2. Delatte, Anne L, Lopez-Villavicencio A (2012) Asymmetry Exchange Rate Pass-Through: Evidence from Major Countries. Journal of Macroeconomics 34: 833-844.

3. Verheyen F (2013) Interest Rate Pass-Through in the EMU-New Evidence Using Nonlinear ARDL Framework. Economics Bulletin 33: 729-739.
4. Bahmani-Oskooee M, Fariditavana H (2014) Do Exchange Rate Changes have Symmetric Effect on the S-Curve? Economics Bulletin 34: 164-173.

5. Bahmani-Oskooee M, Fariditavana H (2015) Nonlinear ARDL Approach, Asymmetric Effects and the J-Curve. Journal of Economic Studies 42: 519-530.

6. Bahmani-Oskooee M, Fariditavana H (2016) Nonlinear ARDL Approach and the J-Curve Phenomenon. Open Economies Review 27: 51-70.

7. Bahmani-Oskooee M, Bahmani S (2015) Nonlinear ARDL Approach and the Demand for Money in Iran. Economics Bulletin 35: 381-391.

8. Valadkhani A (2015) Asymmetric Size-Dependent Effects of the Output Gap on Inflation: US Evidence from the Last Half a Century. Applied Economics 47: 3525-3539.

9. Bahmani-Oskooee M, Ghodsi H (2016) Do Changes in the Fundamentals have Symmetric or Asymmetric Effects on House Prices? Evidence from 52 States of the U.S. Applied Economics 48: 2912-2936.

10. Li J, Lee J (2010) Single-Equation ADL Test for Threshold Cointegration Journal of Time Series Analysis 31: 241-254.

11. Boswijk P (1994) Testing for an Unstable Root in Conditional and Structural Error Correction Models. Journal of Econometric 63: 37-60.

12. Banerjee A, Dolado JH, Mestre R (1998) Error-Correction Mechanism Tests for Cointegration in a Single-Equation Framework. Journal of Time Series Analysis 19: 267-83.

13. Balke NS, Fomby TB (1997) Threshold Cointergration. International Economic Review 38: 627-645. 